EXPERIMENTAL STUDY

\title{
Immunohistochemical detection of GHRH and its receptor splice variant 1 in primary human breast cancers
}

\author{
Ioulia Chatzistamou ${ }^{1}$, Andrew V Schally ${ }^{4,5}$, Hippokratis Kiaris ${ }^{3}$, Ekaterini Politi ${ }^{2}$, Jozsef Varga ${ }^{4,5}$, George Kanellis ${ }^{2}$, \\ Anastasios Kalofoutis ${ }^{3}$, Agatha Pafiti $^{1}$ and Helen Koutselini ${ }^{2}$ \\ Departments of ${ }^{1}$ Pathology and ${ }^{2}$ Cytopathology, Aretaieion University Hospital, ${ }^{3}$ Department of Biological Chemistry, Medical School, \\ University of Athens, M Asias 75 str., Athens 115 27, Greece, ${ }^{4}$ Endocrine, Polypeptide and Cancer Institute, Veterans Affairs Medical Center and \\ ${ }^{5}$ Section of Experimental Medicine, Department of Medicine, Tulane University School of Medicine, New Orleans, Louisiana 70112, USA \\ (Correspondence should be addressed to H Kiaris; Email: hkiaris@med.uoa.gr)
}

\begin{abstract}
Objective: GHRH is secreted by the hypothalamus and, upon binding to specific GHRH receptors in the pituitary, stimulates growth hormone $(\mathrm{GH})$ production and release from the pituitary. In addition to this neuroendocrine action, accumulated evidence implies additional roles for GHRH in carcinogenesis in non-pituitary tissues. In vitro and in vivo studies have shown that splice variant 1 (SV1) of the GHRH receptor, which is widely expressed in non-pituitary tissues and cancers, can mediate the proliferative effects of GHRH. The aim of the present study was to investigate the operation of an autocrine stimulatory loop between GHRH and SV1 in primary breast tumors.

Design: Fifty-three primary breast tumors were evaluated for GHRH and SV1 expression.

Methods: Expression of GHRH and SV1 was assessed by immunohistochemistry using anti-GHRH SV95 and anti-SV1 2317/5 polyclonal antibodies.

Results: About 40\% of the specimens tested express GHRH and/or SV1 (approx. 25\% each), while in $35 \%$ of these positive specimens co-expression of these antigens was detected $(P<0.01)$. Furthermore, a correlation of GHRH, but not SV1, expression was detected in lobular compared with ductal carcinomas.

Conclusions: These results constitute the first demonstration for the expression of GHRH and SV1 in primary breast cancers, and provide evidence for the operation of an autocrine stimulatory loop between GHRH and SV1 in primary cancers. Our findings indicate that GHRH analogs could have diagnostic and therapeutic applications for the management of breast cancer.
\end{abstract}

European Journal of Endocrinology 151 391-396

\section{Introduction}

Growth hormone-releasing hormone (GHRH) is secreted by the hypothalamus and, after binding to specific GHRH receptors in the pituitary, stimulates growth hormone $(\mathrm{GH})$ release $(1-3)$. GH, in turn, stimulates the production of insulin-like growth factor-I (IGF-I) in the liver, which is a mitogen for various cell types (4).

Besides this neuroendocrine action, accumulated evidence points to additional actions of GHRH in non-pituitary tissues, especially neoplasms, by direct mechanisms. This evidence includes the expression pattern of this neuropeptide which suggests that GHRH is detected in many types of non-pituitary tumors (reviewed in 5). In addition, treatment of various experimental cancers, such as lung, brain, prostate, endometrial, ovarian and breast carcinomas, with antagonistic analogs of GHRH significantly inhibits their growth. This antitumor action of GHRH has been demonstrated in both in vivo experiments involving transplantable tumors in mice, and in in vitro cell culture conditions, in which by definition the endocrine GHRH/GH/IGF-I axis is not operational (reviewed in 4,5$)$. Thus, a role for GHRH as an autocrine/paracrine growth factor has been established $(6-15)$. However, the receptor that mediates the proliferative effects of GHRH in non-pituitary tissues remains obscure. While the receptor for GHRH, in its pituitary form, is not expressed in extrapituitary tissues, a splice variant (SV) of this protein has been shown to be expressed in a wide range of non-pituitary tissues and experimental cancers $(16,17)$. This protein, which lacks a short extracellular portion of the full-length receptor, was 
shown to be capable of mediating the mitogenic effects of GHRH and to possess, in addition to its ligand-dependent activity, ligand-independent activity in stimulating cell proliferation $(18,19)$. While the aforementioned evidence demonstrates that slice variant 1 (SV1) can mediate the growth-promoting effects of GHRH, to what extent the operation of such an autocrine stimulatory loop reflects the conditions of primary cancers remains poorly understood.

In the present study, we evaluated primary breast tumors, a cancer cell type which previously was shown to express biologically active GHRH and to respond significantly to the antagonists of GHRH, for expression of GHRH and SV1 $(20-22)$. Our results indicate that the expression of GHRH and SV1 is not only detectable, but also correlated, providing an initial demonstration for the operation of this autocrine stimulatory loop in primary cancers.

\section{Materials and methods}

\section{Specimens}

Formalin-fixed paraffin-embedded tissues from 53 patients who had been surgically treated were collected from the Surgical Pathology archives of the Department of Pathology, Aretaieion Hospital, University of Athens, Athens. The study was approved by the Hospital Ethics and Scientific Research Committee. All patients were treated by mastectomy with axillary lymph node dissection. Histological grading of invasive ductal carcinomas takes into consideration the growth pattern of the tumors as well as cytological features of differentiation. The parameters measured were the extent of tubule formation, nuclear hyperchromasia and mitotic rate, and the histological grade was expressed in three categories: well differentiated (grade I), intermediate (grade II), and poorly differentiated (grade III).

\section{Immunohistochemistry}

Four-mm thick sections from representative paraffinembedded blocks of 53 breast adenocarcinomas were collected onto poly-L-lysine-coated slides and stained for GHRH and SV1 antigens. The immunohistochemical detection of GHRH was carried out with rabbit anti-GHRH SV95 (23) polyclonal antibody, diluted with $1 \times$ phosphate buffer saline (PBS) at 1:100, using the Kwik-DAB kit (ThermoShandon, Pittsburgh, PA, USA) according to the manufacturer's instructions. The immunohistochemical detection of SV1 was performed with rabbit anti-SV1 polyclonal antibody $2317 / 5$ diluted with $1 \times$ PBS at $1: 10^{4}$. The $2317 / 5$ anti-SV1 antibody was designed and produced by J Horvath, J Varga, M Zarandi and K Groot in the laboratory of one of us (A V S); its development will be reported elsewhere. Negative controls in which the primary antibody has been omitted has also been included in the analysis (data not shown). Specimens were evaluated for positive staining and classified according to the percentage of positive cells into the following categories: $1-10 \%, \pm ; 11-30 \%,+; 31-70 \%,++$; $71-100 \%$, +++ . Images shown were obtained by Pro-image Analysis Software (Media Cybernetics, Inc., Silver Springs, MD, USA).

\section{Statistical analysis}

Statistical analysis was performed with the chi-square test and results were considered significant when $P<0.05$.

\section{Results}

GHRH expression was detected in 13 (25\%) and SV1 in $14(26 \%)$ out of the 53 cases tested (Table 1$)$. Immunoreactivity was cytoplasmic in all cases and it ranged from mild $( \pm)$ to intense $(+++)$ (Figs 1 and 2). Among the 20 (38\%) cases identified as positive for either GHRH or SV1 expression, in 7 of them (35\% of the specimens expressing either GHRH or SV1, or $13 \%$ among the total number of specimens tested), a co-expression of the ligand and the receptor was revealed $(P<0.01)$. No association between SV1 expression and the histological type of the breast cancer was found, but GHRH was detected at a higher ratio in lobular (3 out of $6,50 \%$ ) than in ductal (10 out of $42,23 \%$ ) carcinomas. For the latter analysis, some cases in which a mixed type carcinoma was found, being both ductal and lobular and/or mucinous, as well as the single papillary specimen, were excluded (Table 1).

\section{Discussion}

GHRH is a neuropeptide that plays an essential role in the stimulation of the GHRH/GH/IGF-1 axis. The accumulated evidence attributes to GHRH a direct role in tumorigenesis and implies that in certain cases GHRH fulfills the criteria for being considered as an autocrine growth factor. This role was initially demonstrated in small cell lung carcinoma and subsequently shown in other tumors as well $(5,6)$. Consistent with this notion are reports claiming the ectopic production of GHRH by several non-pituitary cancers, as well as the demonstration of the potent antitumor activity of GHRH antagonists by mechanisms that frequently bypass the GH/IGF-I axis. It is noteworthy that the receptor for GHRH is absent from virtually all non-pituitary tissues tested. However, the identification of splice variants of GHRH receptors in such tissues implies that they may function as the receptors that mediate the mitogenic effects of GHRH in primary cancers. While preliminary initial characterization of the predominant splice variant of GHRH receptor, namely SV1, suggests 
Table 1 Clinicopathological data and expression of GHRH and GHRH receptor splice variant SV1 in human breast carcinoma specimens.

\begin{tabular}{|c|c|c|c|c|c|c|}
\hline Case no. & $\begin{array}{c}\text { Age } \\
\text { (years) }\end{array}$ & Histology* & $\begin{array}{c}\text { Grade } \\
(\mathrm{FIGO}) \dagger\end{array}$ & $\begin{array}{l}\text { No. of metastatic } \\
\text { lymph nodes }\end{array}$ & $\begin{array}{c}\text { GHRH } \\
\text { immunostaining } \dagger\end{array}$ & $\begin{array}{c}\text { SV1 } \\
\text { immunostaining }\end{array}$ \\
\hline 1 & 72 & D & II & $0 / 19$ & \pm & ++ \\
\hline 2 & 72 & L & & & - & - \\
\hline 3 & 63 & D & II & $10 / 16$ & + & + \\
\hline 4 & 48 & D & I & $1 / 15$ & - & + \\
\hline 5 & 55 & D & II & & - & - \\
\hline 6 & 80 & D & II & $2 / 10$ & - & - \\
\hline 7 & 45 & D & III & $9 / 20$ & - & - \\
\hline 8 & 56 & $\mathrm{~L}$ & & $8 / 17$ & + & - \\
\hline 9 & 50 & D & II & 2/15 & - & - \\
\hline 10 & 42 & D & III & $12 / 14$ & - & - \\
\hline 11 & 61 & D & III & $3 / 28$ & - & + \\
\hline 12 & 51 & D & III & $0 / 9$ & - & - \\
\hline 13 & 63 & D & III & $4 / 11$ & - & - \\
\hline 14 & 76 & D & III & & - & + \\
\hline 15 & 37 & $\mathrm{D}, \mathrm{P}, \mathrm{M}$ & II & $0 / 15$ & - & - \\
\hline 16 & 69 & D & III & $3 / 10$ & - & - \\
\hline 17 & 67 & $\mathrm{D}, \mathrm{L}$ & II & $5 / 15$ & - & - \\
\hline 18 & 73 & D & III & $0 / 10$ & ++ & - \\
\hline 19 & 74 & $\mathrm{~L}$ & & & + & - \\
\hline 20 & 70 & D & III & & - & - \\
\hline 21 & 72 & D & 1 & $0 / 13$ & - & ++ \\
\hline 22 & 70 & D & III & & - & \pm \\
\hline 23 & 77 & D & III & 2/18 & + & - \\
\hline 24 & 72 & D & III & $15 / 16$ & ++ & + \\
\hline 25 & 62 & $L, M, D^{\prime S}$ & & & - & - \\
\hline 26 & 58 & D & III & $0 / 19$ & - & + \\
\hline 27 & 56 & D & III & & - & - \\
\hline 28 & 70 & D & II & $0 / 10$ & - & - \\
\hline 29 & 68 & D & II & $3 / 24$ & + & + \\
\hline 30 & 56 & D & & & - & - \\
\hline 31 & 71 & D & III & $12 / 23$ & - & - \\
\hline 32 & 27 & D & II & $2 / 9$ & - & - \\
\hline 33 & 66 & L & & $1 / 28$ & - & +++ \\
\hline 34 & 76 & $\mathrm{P}$ & & $0 / 9$ & - & - \\
\hline 35 & 58 & D & III & $0 / 26$ & - & - \\
\hline 36 & 72 & D & III & $0 / 5$ & + & + \\
\hline 37 & 47 & D & III & & - & - \\
\hline 38 & 72 & D & II & $1 / 8$ & - & - \\
\hline 39 & 65 & D & III & $3 / 13$ & - & - \\
\hline 40 & 58 & D & II & $4 / 8$ & - & - \\
\hline 41 & 44 & D & III & & - & - \\
\hline 42 & 51 & $D^{1 S}$ & & $0 / 13$ & - & - \\
\hline 43 & 74 & D & II & $0 / 12$ & - & - \\
\hline 44 & 54 & D & II & $5 / 13$ & - & - \\
\hline 45 & 72 & D & II & 0/12 & - & - \\
\hline 46 & 72 & $\mathrm{D}, \mathrm{L}$ & II & $16 / 19$ & - & - \\
\hline 47 & 81 & $\mathrm{D}$ & II & $0 / 12$ & - & - \\
\hline 48 & 49 & L & & $0 / 11$ & +++ & - \\
\hline 49 & 64 & D & II & $2 / 16$ & \pm & + \\
\hline 50 & 76 & $\mathrm{~L}$ & & $1 / 20$ & - & - \\
\hline 51 & 60 & D & III & $0 / 17$ & - & - \\
\hline 52 & 73 & D & II & $1 / 16$ & + & + \\
\hline 53 & 85 & $D$ & III & $4 / 10$ & + & - \\
\hline
\end{tabular}

* D, ductal; L, lobular; $\mathrm{P}$, papillary; $\mathrm{M}$, mucinous; $^{\text {is }}$, in situ. $\dagger$ See text for details of scoring.

** Positive/total found lymph nodes.

that it is capable of mediating the stimulatory effects of GHRH in non-pituitary tissues upon exogenous expression, it is unclear whether it functions as such in primary tumors. If the latter hypothesis were correct, it would be expected that the expression of this receptor splice variant SV1, and its ligand GHRH, would be correlated in primary cancers. Therefore, we have undertaken an immunohistochemical analysis for the detection of GHRH and SV1 expression in primary breast cancers, a tumor type previously shown to 


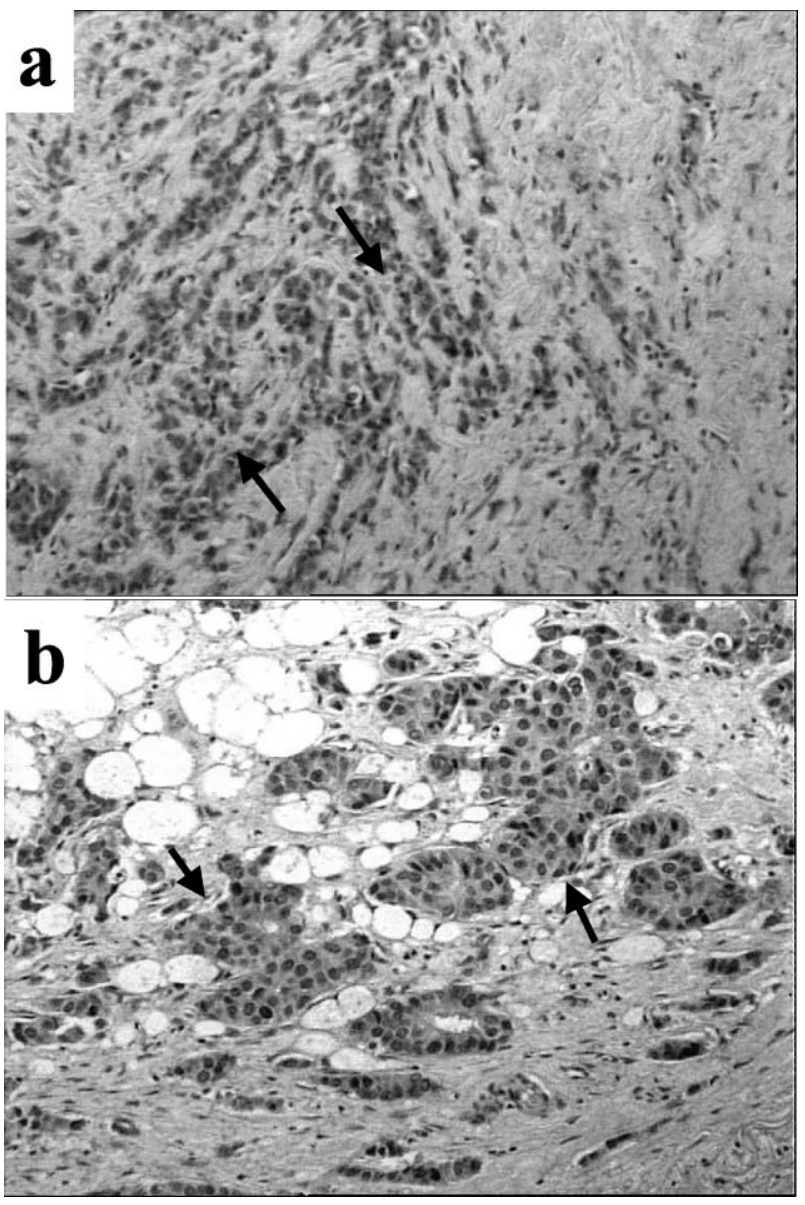

Figure 1 GHRH immunoreactivity in primary human breast tumors: (a) invasive lobular carcinoma; (b) invasive ductal carcinoma. Arrows indicate positively stained cells.

respond to GHRH antagonists. Our results confirmed the hypothesis that GHRH and SV1 are co-expressed in primary breast cancers. Although only a limited number of specimens, about $25 \%$, expressed either GHRH or SV1, 35\% of these specimens were positive for both $(P<0.01)$, which corresponds to $13 \%$ among the total number of specimens tested. It has to be mentioned that given the methodology employed in the present study, our results might be underestimates and that molecular analyses including RT-PCR and/or in situ hybridization might have revealed a higher incidence of GHRH and SV1 positivity. Considering that SV1 is acting as a membrane receptor, in a manner analogous to that of GHRH receptor, the cytoplasmic staining detected in our analysis might be interesting and suggestive of additional roles of SV1. However, this finding should be considered with caution since immunohistochemistry followed by light microscopy is not the most appropriate technique for localization studies at the sub-cellular level. Confocal analyses in combination with immunofluorescence or other analogous approaches should be followed in
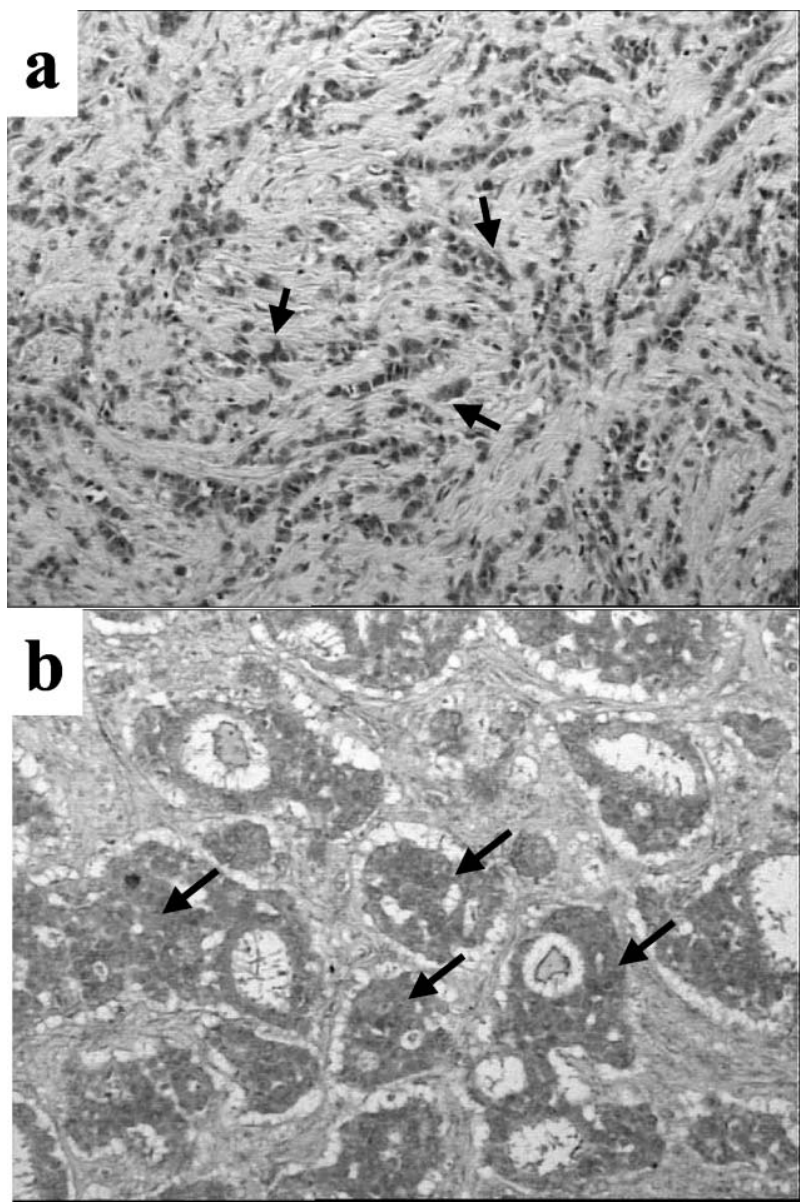

Figure 2 SV1 immunoreactivity in primary human breast tumors: (a) invasive lobular carcinoma; (b) invasive ductal carcinoma. Arrows indicate positively stained cells.

order to investigate with high accuracy the precise intracellular localization of SV1.

That certain cases were positive for GHRH alone, besides the fact that it may be due to the reduced sensitivity of our assay in detecting the splice variant receptors for GHRH, is consistent with the notion that GHRH can act through other receptors, namely the receptor for the vasoactive intestinal peptide or the pituitary adenyl cyclase activating polypeptide. Thus, GHRH, even in the absence of SV1, may bind to other homologous receptors, eliciting mitogenic responses. Furthermore, the cancer cells probably are not the only targets for the locally produced GHRH, and an effect on the tumoral stroma should also be considered. This is in agreement with previous findings showing that an agonist of GHRH can stimulate the proliferation and increase the levels of c-myc mRNA in normal human dermal fibroblasts (24). In addition, a recent study involving the analysis of GHRH expression in primary endometrial carcinomas by a combination of in situ hybridization analysis and immunohistochemistry demonstrated that while the GHRH mRNA-producing 
cells exhibited a mosaic pattern, the peptide itself was detected in a more uniform pattern implying a paracrine, most likely a stromal, action (25).

SV1 was detected in certain cases in which GHRH expression was absent. Recent findings suggest that SV1, besides its ligand GHRH-dependent activity, also possesses ligand-independent activity, consisting of the stimulation of cell proliferation in the absence of GHRH (19). Consequently, this receptor may play a role in the development of the disease even without reaching its maximal stimulation which occurs only in the presence of ligand binding.

Our results show that GHRH expression is detected predominantly in the lobular as compared with the ductal carcinomas. While the number of specimens tested is limited and does not permit reliable statistical analysis and therefore has to be confirmed by further studies, it raises interesting possibilities regarding our understanding of the mechanisms of pathogenesis of the disease.

Collectively, this study provides the first demonstration that GHRH and splice variant SV1 of its receptor are expressed in primary breast cancers and implies that the operation of an autocrine stimulatory loop between this ligand and the corresponding receptor is associated with the development of the disease. These findings also suggest that approaches to therapy of breast cancer based on antagonists of GHRH merit an investigation.

\section{Acknowledgements}

We thank Dr Gabor Halmos for critical reading of the manuscript. We are also grateful to P Kollia-Lariou and K Ploumi for help in specimen collection and processing.

\section{References}

1 Schally AV \& Comaru-Schally AM. Agonistic analogs of growth hormone-releasing hormone $(\mathrm{GH}-\mathrm{RH})$ : endocrine and growth studies. In Growth Hormone Secretagogues in Clinical Practice, pp 14-31. Eds BB Bercu \& RF Walker. New York: Marcel Dekker, 1998.

2 Schally AV, Steelman S \& Bowers CY. Effect of hypothalamic extracts on the release of growth hormone in vitro. Proceedings of the Society for Experimental Biology and Medicine 1965119 208-212.

3 Krulich L, Dhariwal APS \& McCann SM. Stimulatory and inhibitory effects of purified hypothalamic extracts on growth hormone release from rat pituitary in vitro. Endocrinology $1968 \mathbf{8 3}$ 783-790.

4 Schally AV \& Varga JL. Antagonistic analogs of growth hormonereleasing hormone: new potential antitumor agents. Trends in Endocrinology and Metabolism 199910 383-391.

5 Kiaris H, Koutsilieris M, Kalofoutis A \& Schally AV. Growth hormone-releasing hormone and extra-pituitary tumorigenesis: therapeutic and diagnostic applications of growth hormonereleasing hormone antagonists. Expert Opinion in Investigational Drugs 200312 1385-1394.

6 Kiaris H, Schally AV, Varga JL, Groot K \& Armatis P. Growth hormone-releasing hormone: an autocrine growth factor for small cell lung carcinoma. PNAS 199996 3098-3103.
7 Busto R, Schally AV, Varga JL, Garcia-Fernandez MO, Groot K, Armatis P \& Szepeshazi K. The expression of growth hormonereleasing hormone $(\mathrm{GHRH})$ and splice variants of its receptor in human gastroenteropancreatic carcinomas. PNAS 200299 11866-11871.

8 Busto R, Schally A, Braczkowski R, Plonowski A, Krupa M, Groot K, Armatis P \& Varga J. Expression of mRNA for growth hormonereleasing hormone and splice variants of GHRH receptors in human malignant bone tumors. Regulatory Peptides 2002108 47-53.

9 Chatzistamou I, Schally AV, Varga JL, Groot K, Busto R, Armatis P \& Halmos G. Inhibition of growth and metastases of MDA-MB435 human estrogen-independent breast cancers by an antagonist of growth hormone-releasing hormone. Anticancer Drugs 2001 $12761-768$.

10 Zeitler P \& Siriwardana G. Antagonism of endogenous growth hormone-releasing hormone (GHRH) leads to reduced proliferation and apoptosis in MDA231 breast cancer cells. Endocrine 200218 85-90.

11 Chatzistamou I, Schally AV, Varga JL, Groot K, Armatis P, Busto R \& Halmos G. Antagonists of growth hormone-releasing hormone and somatostatin analog RC-160 inhibit the growth of the OV1063 human epithelial ovarian cancer cell line xenografted into nude mice. Journal of Clinical Endocrinology and Metabolism 2001 $862144-2152$.

12 Csernus EJ, Schally AV, Kiaris H \& Armatis P. Inhibition of growth, production of insulin-like growth factor-II (IGF-II), and expression of IGF-II mRNA of human cancer cell lines by antagonistic analogs of growth hormone-releasing hormone in vitro. PNAS 1999 $963098-3103$.

13 Szepeshazi K, Schally AV, Groot K, Armatis P, Hebert F \& Halmos G. Antagonists of growth hormone-releasing hormone (GH-RH) inhibit in vivo proliferation of experimental pancreatic cancers and decrease IGF-II levels in tumors. European Journal of Cancer 2000 $36128-136$.

14 Szepeshazi K, Schally AV, Groot K, Armatis P, Halmos G, Hebert F, Szende B, Varga JL \& Zarandi M. Antagonists of growth hormonereleasing hormone (GH-RH) inhibit IGF-II production and growth of HT-29 human colon cancers. British Journal of Cancer $2000 \mathbf{8 2}$ $1724-1731$.

15 Braczkowski R, Schally AV, Plonowski A, Varga JL, Groot K, Krupa M \& Armatis P. Inhibition of proliferation in human MNNG/HOS osteosarcoma and SK-ES-1 Ewing sarcoma cell lines in vitro and in vivo by antagonists of growth hormone-releasing hormone. Cancer 200295 1735-1745.

16 Halmos G, Schally AV, Varga JL, Plonowski A, Rekasi Z \& Czompoly T. Human renal cell carcinoma expresses distinct binding sites for growth hormone-releasing hormone. PNAS 200097 10555-10560.

17 Rekasi Z, Czompoly T, Schally AV \& Halmos G. Isolation and sequencing of cDNAs for splice variants of growth hormonereleasing hormone receptors from human cancers. PNAS 2000 $9710561-10566$.

18 Kiaris H, Schally AV, Busto R, Halmos G, Artavanis-Tsakonas S \& Varga JL. Expression of splice variant for GHRH receptor SV1 mediates mitogenic effects in 3T3 fibroblasts. PNAS 200299 196-200.

19 Kiaris H, Chatzistamou I, Schally AV, Halmos G, Varga JL, Koutselini H \& Kalofoutis A. Ligand-dependent and -independent effects of splice variant 1 of growth hormone-releasing hormone receptor. PNAS $2003 \mathbf{1 0 0} 9512-9517$.

20 Kahan Z, Varga JL, Schally AV, Rekasi Z, Armatis P, Chatzistamou I, Czompoly T \& Halmos G. Antagonists of growth hormone-releasing hormone arrest the growth of MDA-MB-468 estrogen-independent human breast cancers in nude mice. Breast Cancer Research and Treatment $20006 \mathbf{6 0} 71-79$.

21 Chatzistamou I, Schally AV, Varga JL, Groot K, Busto R, Armatis P \& Halmos G. Inhibition of growth and metastases of MDA-MB435 human estrogen-independent breast cancers by an antagonist of growth hormone-releasing hormone. Anticancer Drugs 2001 $12761-768$. 
22 Kahan Z, Arencibia JM, Czernus VJ, Groot K, Kineman RD, Robinson WR \& Schally AV. Expression of growth hormonereleasing hormone (GH-RH) messenger ribonucleic acid and the presence of biologically active GH-RH in human breast, endometrial and ovarian cancers. Journal of Clinical Endocrinology and Metabolism $1999 \mathbf{8 4} 582-589$.

23 Groot K, Csernus VJ, Pinski J, Zsigo J, Rekasi Z, Zarandi M \& Schally AV. Development of a radioimmunoassay for some agonists of growth hormone-releasing hormone. International Journal of Peptide and Protein Research 199341 162-168.

24 Kiaris H, Schally AV \& Armatis P. Direct action of growth hormone-releasing hormone agonist JI-38 on normal human diploid fibroblasts: evidence from studies on cell proliferation and c-myc oncogene expression. Regulatory Peptides 200196 119-124.

25 Chatzistamou I, Schally AV, Pafiti A, Kiaris H \& Koutselini H. Expression of growth hormone-releasing hormone in human primary endometrial carcinomas. European Journal of Endocrinology $2002147381-386$

Received 3 May 2004

Accepted 24 May 2004 